\title{
Associations of height, leg length, and lung function with cardiovascular risk factors in the Midspan Family Study
}

\author{
D Gunnell, E Whitley, M N Upton, A McConnachie, G Davey Smith, G C M Watt
}

J Epidemiol Community Health 2003;57:141-146

See end of article for authors' affiliations

Correspondence to: Dr D Gunnell, Department of Social Medicine, Canynge Hall, Whiteladies Road, Bristol BS8 2PR, UK; D.J.Gunnell@bristol.ac.uk

Accepted for publication 6 May 2002

\begin{abstract}
Background: Taller people and those with better lung function are at reduced risk of coronary heart disease (CHD). Biological mechanisms for these associations are not well understood, but both measures may be markers for early life exposures. Some studies have shown that leg length, an indicator of pre-pubertal nutritional status, is the component of height most strongly associated with CHD risk. Other studies show that height-CHD associations are greatly attenuated when lung function is controlled for. This study examines (1) the association of height and the components of height (leg length and trunk length) with $\mathrm{CHD}$ risk factors and (2) the relative strength of the association of height and forced expiratory volume in one second $\left(\mathrm{FEV}_{1}\right)$ with risk factors for $\mathrm{CHD}$.

Subjects and methods: Cross sectional analysis of data collected at detailed cardiovascular screening examinations of 1040 men and 1298 women aged 30-59 whose parents were screened in 1972-76. Subjects come from 1477 families and are members of the Midspan Family Study.

Setting: The towns of Renfrew and Paisley in the West of Scotland.

Results: Taller subjects and those with better lung function had more favourable cardiovascular risk factor profiles, associations were strongest in relation to FEV 1 . Higher FEV, was associated with lower blood pressure, cholesterol, glucose, fibrinogen, white blood cell count, and body mass index. Similar, but generally weaker, associations were seen with height. These associations were not attenuated in models controlling for parental height. Longer leg length, but not trunk length, was associated with lower systolic and diastolic blood pressure. Longer leg length was also associated with more favourable levels of cholesterol and body mass index than trunk length.

Conclusions: These findings provide indirect evidence that measures of lung development and pre-pubertal growth act as biomarkers for childhood exposures that may modify an individual's risk of developing CHD. Genetic influences do not seem to underlie height-CHD associations.
\end{abstract}

A ssociations between height and coronary heart disease (CHD) have been found in a number of prospective studies $^{1-6}$ - CHD mortality decreases with increasing stature. This finding generally persists after adjustment for possible confounding factors, such as social class and smoking. There are a number of possible explanations for these associations. Firstly, as well as being under genetic control, height is a marker for exposures influencing childhood growth—such as diet, infection, or psychological stress - which may themselves be important in the aetiology of CHD. ${ }^{7}$ Secondly, coronary vessel diameter increases with height and this in turn may be associated with a decreased risk of luminal occlusion. ${ }^{8}$ Thirdly, loss of stature ("shrinkage") may occur in the early stages of disease and thus height-disease associations may in part reflect the presence of pre-existing ill health. ${ }^{6}$ Fourthly, genes influencing height may be closely linked to those affecting CHD risk. Finally, the growth hormone (GH) insulin-like growth factor (IGF) axis may be important. This axis influences childhood growth and is also thought to play a part in cardiovascular physiology as suggested by the observation that adults with hypopituitarism are at increased risk of $\mathrm{CHD}$ and have adverse cardiovascular risk profiles. ${ }^{10}$

A recent refinement to analyses of the link between height and CHD has been to investigate associations of the components of height—leg length and trunk length-with disease risk. Leg length is a marker of environmental influences on childhood growth before puberty as, up until puberty, height increases are in greater part attributable to leg growth. ${ }^{11}{ }^{12}$ Furthermore, secular increases in height, representing improvements in the nutritional status of populations, appear to arise more from increases in leg length, rather than trunk growth. ${ }^{13}{ }^{14}$ It is therefore of interest that in analyses of two cohorts-the Boyd Orr and the Caerphilly studiesassociations between height and CHD risk are found in relation to leg length but not trunk length. ${ }^{15} 7$ In the Caerphilly study short leg length was also associated with insulin resistance. ${ }^{15}$ This seems to support the notion that exposures operating during childhood that influence growth are important in the aetiology of CHD.

There is debate concerning the extent to which the association between height and CHD mortality is attributable to height related differences in lung function. Adjustment for forced expiratory volume in one second $\left(\mathrm{FEV}_{1}\right)$ attenuates ${ }^{25} 16$ height-CHD associations. Furthermore, in a case-control analysis of the relation between height and CHD, where cases and controls were matched for $\mathrm{FEV}_{1}$, no height-mortality association was found.$^{17}$ It is possible that both height and lung function are biomarkers for exposures in childhood that influence growth, lung development, and later heart disease risk. ${ }^{17}$

Based on the detailed cardiovascular screening examinations of 2338 adults aged 30-59, this paper investigates the associations of height, leg length, trunk length, and lung function with cardiovascular risk factors. As the parents of the study children had themselves been examined 20 years earlier, we were also able to assess the extent to whether genetic influences on stature-as indexed by parental height-underlie associations between anthropometry and CHD risk factors.

\section{METHODS}

The subjects upon whom this research is based were offspring of 4064 married couples who were screened in the RenfrewPaisley (Midspan) Study in 1972-76. ${ }^{18}{ }^{19}$ In $1993-4$, attempts were made to trace offspring either through direct contact 
with the original study couple or, where both husband and wife were dead, through contacts with informants mentioned on their death certificate. Altogether 4829 offspring aged 30-59 were identified from 2365 couples with children; 3202 of these offspring lived within 45 minutes of Paisley and Renfrew. Of these, 1040 men and 1298 women from 1477 families completed a questionnaire and examination in 1996-a response rate of $73 \%$. The study protocol was approved by the relevant research ethics committees.

\section{Survey methods}

Information on subjects' personal and family medical history, sociodemographic information, and smoking habits was obtained from detailed self completed questionnaires. Social class for women was based on their own, rather than their partner's, occupation. Examinations were carried out in clinics staffed by six research nurses who rotated between measurement stations. Measurements included: 12 lead ECG; blood pressure-recorded using a Dinamapp 8100, three readings were taken from the left arm with the subject seated and allowed to rest for five minutes-the mean of the last two reading for systolic and diastolic blood pressure was used; non-fasting venous blood samples were analysed for total and HDL cholesterol, fibrinogen ${ }^{20}$ white blood count and glucose; FEV , and FVC were measured using a Vitalograph Spirotrac III. ${ }^{21}$ Standing height and sitting height were measured without shoes in the Frankfort plane to the nearest millimetre using a Holtain stadiometer. Leg length was calculated as the difference between standing height and sitting height, plus the height of the stool. Weight was measured to the nearest $100 \mathrm{~g}$ with Seca digital scales in stockinged feet wearing indoor clothes. Recorded birthweight data were retrieved from birth archives for 677 (29\%) study members.

Parents were examined between 1972-76 when height was measured to the nearest centimetre. We calculated midparental height as the average of mother's and father's height for each subject. Father's social class was determined from information given on regular occupation and classified according to the registrar general's classification. For retired men the last full time occupation was used. Occupational social class was classified as non-manual (social class I-III non-manual) and manual (III manual-V).

\section{Statistical methods}

All statistical analyses were performed using Stata version $6.0{ }^{22}$ Least squares regression was used to calculate age adjusted changes in continuous cardiovascular risk factor levels associated with a one standard deviation increase in subject's height, leg length, trunk length, leg:trunk ratio, and FEV . Likewise logistic regression was used to assess associations with dichotomous risk factors such as smoking and social class. All confidence intervals and p values were based on Huber White robust estimates of variance that accounted for intrafamilial clustering (P Huber, Proceedings of the Fifth Berkley Symposium on Mathematical Statistics and probability 1967).

We assessed the effects on FEV risk factor associations of controlling for physical activity, measured by two questions in a self report questionnaire. The questions assessed levels of activity (a) during day to day activity and (b) during leisure time on 4 point scales.

\section{RESULTS}

Table 1 presents summary statistics for the cardiovascular risk factors examined. For most of the variables complete data were available for most subjects. The exceptions were recorded birth weight (available for $29 \%$ of subjects), HDL cholesterol $(84 \%)$, and white cell count $(89 \%)$. The social class distribution of survey members was slightly skewed towards the upper social classes because eligibility required that (a) the subject's parents had participated in 1972-76, (b) their parents were alive and traceable in 1993-4 (or traceable via the death certificate informant), and (c) the subjects themselves had agreed to take part in the study and non-response at each of the stages is likely to be socially patterned. Furthermore, in women, social class was based on their own occupations and many were in clerical employment.

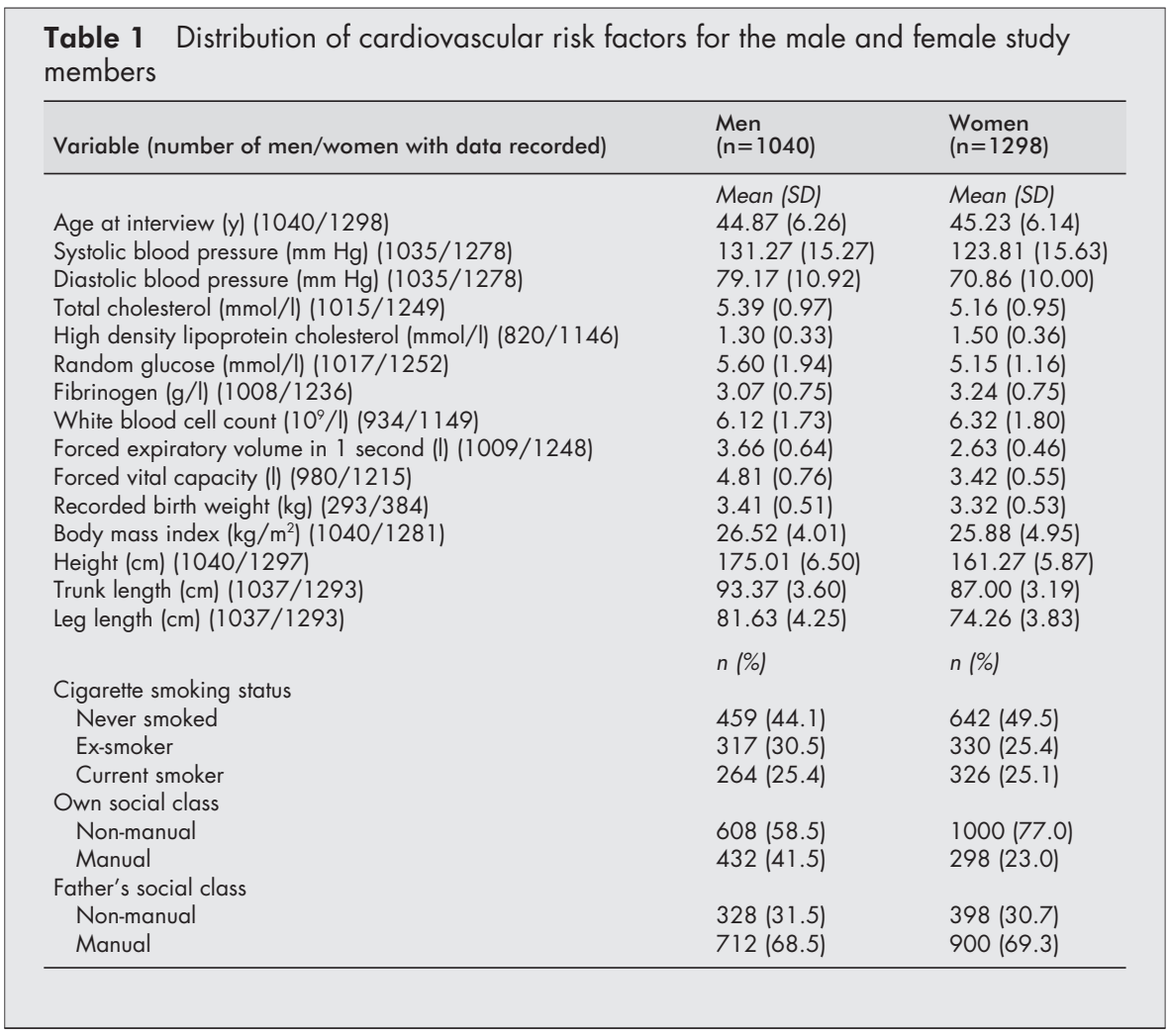


Table 2 Age adjusted change in levels of cardiovascular risk factors per standard deviation (SD) increase in (a) height, (b) leg length, (c) trunk length, (d) leg: trunk ratio and (e) forced expiratory volume in 1 second $\left(\mathrm{FEV}_{1}\right)$. ${ }^{*}$ (continuous variables)

\begin{tabular}{|c|c|c|c|c|c|}
\hline & $\begin{array}{l}\text { (a) Height } \\
\text { (change }(95 \% \mathrm{Cl}), \mathrm{p} \\
\text { value per SD increase in } \\
\text { height) }\end{array}$ & $\begin{array}{l}\text { (b) Leg length } \\
\text { (change }(95 \% \mathrm{Cl}), \mathrm{p} \\
\text { value per SD increase in } \\
\text { leg length) }\end{array}$ & $\begin{array}{l}\text { (c) Trunk length } \\
\text { (change }(95 \% \mathrm{Cl}), \mathrm{p} \\
\text { value per SD increase in } \\
\text { trunk length) }\end{array}$ & $\begin{array}{l}\text { (d) Leg: Trunk ratio } \\
\text { (change }(95 \% \mathrm{CI}), \mathrm{p} \\
\text { value per } \mathrm{SD} \text { increase in } \\
\text { ratio) }\end{array}$ & $\begin{array}{l}\text { (e) } \mathrm{FEV}_{1} \\
\text { (change }(95 \% \mathrm{Cl}), \mathrm{p} \\
\text { value per SD increase in } \\
\mathrm{FEV}_{1} \text { ) }\end{array}$ \\
\hline \multicolumn{6}{|c|}{ Systolic blood pressure (mm Hg) } \\
\hline Men & $\begin{array}{l}-0.50(-1.44 \text { to } 0.44) \\
p=0.29\end{array}$ & $\begin{array}{l}-1.14(-2.06 \text { to }-0.21) \\
p=0.02\end{array}$ & $\begin{array}{l}0.42(-0.53 \text { to } 1.38) \\
p=0.39\end{array}$ & $\begin{array}{l}-1.48(-2.41 \text { to }-0.54) \\
p=0.002\end{array}$ & $\begin{array}{l}-1.66 \quad(-2.75 \text { to }-0.57) \\
p=0.003\end{array}$ \\
\hline Women & $\begin{array}{l}-0.68 \quad(-1.53 \text { to } 0.17) \\
p=0.12\end{array}$ & $\begin{array}{l}-1.09(-1.93 \text { to }-0.25) \\
p=0.01\end{array}$ & $\begin{array}{l}0.08 \quad(-0.79 \text { to } 0.95) \\
p=0.86\end{array}$ & $\begin{array}{l}-1.17(-2.02 \text { to }-0.32) \\
p=0.01\end{array}$ & $\begin{array}{l}-1.81 \quad(-2.77 \text { to }-0.85) \\
p<0.001\end{array}$ \\
\hline \multicolumn{6}{|c|}{ Diastolic blood pressure $(\mathrm{mm} \mathrm{Hg})$} \\
\hline Men & $\begin{array}{l}-0.25(-0.93 \text { to } 0.44) \\
p=0.48\end{array}$ & $\begin{array}{l}-0.87(-1.56 \text { to }-0.18) \\
p=0.01\end{array}$ & $\begin{array}{l}0.60 \quad(-0.06 \text { to } 1.27) \\
p=0.07\end{array}$ & $\begin{array}{l}-1.32(-1.98 \text { to }-0.67) \\
p=0.02\end{array}$ & $\begin{array}{l}-1.11(-1.82 \text { to }-0.39) \\
p=0.002\end{array}$ \\
\hline Women & $\begin{array}{l}-0.18(-0.76 \text { to } 0.41) \\
p=0.55\end{array}$ & $\begin{array}{l}-0.49(-1.06 \text { to } 0.08) \\
p=0.09\end{array}$ & $\begin{array}{l}0.28 \quad(-0.31 \text { to } 0.87) \\
p=0.35\end{array}$ & $\begin{array}{l}-0.71(-1.27 \text { to }-0.15) \\
p=0.01\end{array}$ & $\begin{array}{l}-0.53(-1.15 \text { to } 0.10) \\
p=0.10\end{array}$ \\
\hline \multicolumn{6}{|c|}{ Total cholesterol (mmol/1) } \\
\hline Men & $\begin{array}{l}-0.13(-0.19 \text { to }-0.07) \\
p<0.001\end{array}$ & $\begin{array}{l}-0.12(-0.18 \text { to }-0.07) \\
p<0.001\end{array}$ & $\begin{array}{l}-0.09(-0.15 \text { to }-0.02) \\
p=0.01\end{array}$ & $\begin{array}{l}-0.06(-0.12 \text { to } 0.00) \\
p=0.07\end{array}$ & $\begin{array}{l}-0.10(-0.17 \text { to }-0.04) \\
p=0.001\end{array}$ \\
\hline Women & $\begin{array}{l}-0.10 \quad(-0.16 \text { to }-0.05) \\
p<0.001\end{array}$ & $\begin{array}{l}-0.11 \quad(-0.16 \text { to }-0.06) \\
p<0.001\end{array}$ & $\begin{array}{l}-0.06(-0.11 \text { to }-0.01) \\
p=0.02\end{array}$ & $\begin{array}{l}-0.07(-0.12 \text { to } 0.02) \\
p=0.01\end{array}$ & $\begin{array}{l}-0.12(-0.18 \text { to }-0.06) \\
p<0.001\end{array}$ \\
\hline \multicolumn{6}{|c|}{ High density lipoprotein cholesterol $(\mathrm{mmol} / 1)$} \\
\hline Men & $\begin{array}{l}0.00(-0.02 \text { to } 0.02) \\
p=0.95\end{array}$ & $\begin{array}{l}0.02(-0.01 \text { to } 0.04) \\
p=0.18\end{array}$ & $\begin{array}{l}-0.02(-0.04 \text { to } 0.01) \\
p=0.17\end{array}$ & $\begin{array}{l}0.03(0.00 \text { to } 0.05) \\
p=0.02\end{array}$ & $\begin{array}{l}0.01(-0.01 \text { to } 0.04) \\
p=0.31\end{array}$ \\
\hline Women & $\begin{array}{l}-0.00(-0.02 \text { to } 0.02) \\
p=0.96\end{array}$ & $\begin{array}{l}0.01 \quad(-0.01 \text { to } 0.04) \\
p=0.24\end{array}$ & $\begin{array}{l}-0.02(-0.04 \text { to } 0.00) \\
p=0.09\end{array}$ & $\begin{array}{l}0.01 \quad(0.00 \text { to } 0.05) \\
p=0.02\end{array}$ & $\begin{array}{l}0.02(-0.02 \text { to } 0.03) \\
p=0.47\end{array}$ \\
\hline \multicolumn{6}{|c|}{ Random glucose (mmol/1) } \\
\hline Men & $\begin{array}{l}-0.05(-0.17 \text { to } 0.07) \\
p=0.43\end{array}$ & $\begin{array}{l}-0.10(-0.22 \text { to } 0.03) \\
p=0.13\end{array}$ & $\begin{array}{l}0.03(-0.09 \text { to } 0.15) \\
p=0.65\end{array}$ & $\begin{array}{l}-0.11(-0.23 \text { to } 0.00) \\
p=0.06\end{array}$ & $\begin{array}{l}-0.22(-0.37 \text { to }-0.07) \\
p=0.01\end{array}$ \\
\hline Women & $\begin{array}{l}-0.01 \quad(-0.07 \text { to } 0.05) \\
p=0.73\end{array}$ & $\begin{array}{l}-0.01 \quad(-0.06 \text { to } 0.05) \\
p=0.79\end{array}$ & $\begin{array}{l}-0.01 \quad(-0.08 \text { to } 0.06) \\
p=0.85\end{array}$ & $\begin{array}{l}0.00(-0.07 \text { to } 0.07) \\
p=0.95\end{array}$ & $\begin{array}{l}-0.06(-0.12 \text { to } 0.01) \\
p=0.09\end{array}$ \\
\hline \multicolumn{6}{|c|}{ Fibrinogen (g/l) } \\
\hline Men & $\begin{array}{l}-0.09 \quad(-0.13 \text { to }-0.04) \\
p<0.001\end{array}$ & $\begin{array}{l}-0.05(-0.10 \text { to }-0.01) \\
p=0.02\end{array}$ & $\begin{array}{l}-0.09(-0.14 \text { to }-0.03) \\
p=0.002\end{array}$ & $\begin{array}{l}0.01 \quad(-0.04 \text { to } 0.07) \\
p=0.61\end{array}$ & $\begin{array}{l}-0.17(-0.22 \text { to }-0.11) \\
p<0.001\end{array}$ \\
\hline Women & $\begin{array}{l}-0.06(-0.10 \text { to }-0.02) \\
p=0.01\end{array}$ & $\begin{array}{l}-0.07(-0.12 \text { to }-0.03) \\
p=0.001\end{array}$ & $\begin{array}{l}-0.02(-0.07 \text { to } 0.02) \\
p=0.34\end{array}$ & $\begin{array}{l}-0.06(-0.10 \text { to }-0.01) \\
p=0.01\end{array}$ & $\begin{array}{l}-0.13(-0.18 \text { to }-0.09) \\
p<0.001\end{array}$ \\
\hline \multicolumn{6}{|c|}{ White blood cell count $\left(10^{-9} / 1\right)$} \\
\hline Men & $\begin{array}{l}0.04(-0.09 \text { to } 0.13) \\
p=0.72\end{array}$ & $\begin{array}{l}0.06(-0.06 \text { to } 0.18) \\
p=0.33\end{array}$ & $\begin{array}{l}-0.03(-0.14 \text { to } 0.08) \\
p=0.61\end{array}$ & $\begin{array}{l}0.08 \quad(-0.04 \text { to } 0.20) \\
p=0.20\end{array}$ & $\begin{array}{l}-0.11 \quad(-0.23 \text { to } 0.01) \\
p=0.06\end{array}$ \\
\hline Women & $\begin{array}{l}-0.14(-0.25 \text { to }-0.04) \\
p=0.01\end{array}$ & $\begin{array}{l}-0.04(-0.15 \text { to } 0.07) \\
p=0.46\end{array}$ & $\begin{array}{l}-0.21 \quad(-0.31 \text { to }-0.10) \\
p<0.001\end{array}$ & $\begin{array}{l}0.11 \quad(-0.01 \text { to } 0.22) \\
p=0.06\end{array}$ & $\begin{array}{l}-0.27 \quad(-0.39 \text { to }-0.15) \\
p<0.001\end{array}$ \\
\hline \multicolumn{6}{|c|}{ Forced expiratory volume in 1 second (1) } \\
\hline Men & $\begin{array}{l}0.28 \quad(0.24 \text { to } 0.32) \\
p<0.001\end{array}$ & $\begin{array}{l}0.22(0.19 \text { to } 0.26) \\
p<0.001\end{array}$ & $\begin{array}{l}0.24(0.20 \text { to } 0.28) \\
p<0.001\end{array}$ & $\begin{array}{l}0.04(0.00 \text { to } 0.09) \\
p=0.04\end{array}$ & - \\
\hline Women & $\begin{array}{l}0.20 \quad(0.18 \text { to } 0.22) \\
p<0.001\end{array}$ & $\begin{array}{l}0.15 \quad(0.13 \text { to } 0.18) \\
p<0.001\end{array}$ & $\begin{array}{l}0.18 \quad(0.16 \text { to } 0.21) \\
p<0.001\end{array}$ & $\begin{array}{l}0.02(-0.01 \text { to } 0.05) \\
p=0.13\end{array}$ & - \\
\hline \multicolumn{6}{|c|}{ Forced vital capacity (1) } \\
\hline Men & $\begin{array}{l}0.43(0.38 \text { to } 0.47) \\
p<0.001\end{array}$ & $\begin{array}{l}0.35 \quad(0.30 \text { to } 0.39) \\
p<0.001\end{array}$ & $\begin{array}{l}0.35 \quad(0.30 \text { to } 0.40) \\
p<0.001\end{array}$ & $\begin{array}{l}0.09(0.05 \text { to } 0.14) \\
p<0.001\end{array}$ & - \\
\hline Women & $\begin{array}{l}0.30(0.27 \text { to } 0.33) \\
p<0.001\end{array}$ & $\begin{array}{l}0.24(0.21 \text { to } 0.27) \\
p<0.001\end{array}$ & $\begin{array}{l}0.26 \quad(0.23 \text { to } 0.28) \\
p<0.001\end{array}$ & $\begin{array}{l}0.05(0.02 \text { to } 0.08) \\
p=0.001\end{array}$ & - \\
\hline \multicolumn{6}{|c|}{ Recorded birth weight $(\mathrm{kg})$} \\
\hline Men & $\begin{array}{l}0.12(0.07 \text { to } 0.17) \\
p<0.001\end{array}$ & $\begin{array}{l}0.12(0.06 \text { to } 0.17) \\
p<0.001\end{array}$ & $\begin{array}{l}0.09(0.04 \text { to } 0.14) \\
p=0.001\end{array}$ & $\begin{array}{l}0.05(-0.01 \text { to } 0.11) \\
p=0.08\end{array}$ & $\begin{array}{l}0.09(0.03 \text { to } 0.14) \\
p=0.002\end{array}$ \\
\hline Women & $\begin{array}{l}0.13 \quad(0.08 \text { to } 0.17) \\
p<0.001\end{array}$ & $\begin{array}{l}0.11 \quad(0.05 \text { to } 0.16) \\
p<0.001\end{array}$ & $\begin{array}{l}0.12 \quad(0.06 \text { to } 0.17) \\
p<0.001\end{array}$ & $\begin{array}{l}0.02(-0.04 \text { to } 0.08) \\
p=0.50\end{array}$ & $\begin{array}{l}0.10(0.04 \text { to } 0.16) \\
p=0.001\end{array}$ \\
\hline \multicolumn{6}{|c|}{ Body mass index } \\
\hline Men & $\begin{array}{l}-0.10(-0.37 \text { to } 0.18) \\
p=0.48\end{array}$ & $\begin{array}{l}-0.59(-0.87 \text { to }-0.31) \\
p<0.001\end{array}$ & $\begin{array}{l}0.52(0.24 \text { to } 0.80) \\
p<0.001\end{array}$ & $\begin{array}{l}-0.95(-1.22 \text { to }-0.68) \\
p<0.001\end{array}$ & $\begin{array}{l}-0.40(-0.73 \text { to }-0.08) \\
p=0.01\end{array}$ \\
\hline Women & $\begin{array}{l}-0.54(-0.81 \text { to }-0.26) \\
p<0.001\end{array}$ & $\begin{array}{l}-0.89 \quad(-1.15 \text { to }-0.62) \\
p<0.001\end{array}$ & $\begin{array}{l}0.08 \quad(-0.19 \text { to } 0.36) \\
p=0.55\end{array}$ & $\begin{array}{l}-0.97 \quad(-1.24 \text { to }-0.70) \\
p<0.001\end{array}$ & $\begin{array}{l}-0.45(-0.78 \text { to }-0.12) \\
p=0.01\end{array}$ \\
\hline
\end{tabular}

*All confidence intervals are adjusted for intra-family clustering.

\section{Associations between anthropometry, FEV $_{1}$ and cardiovascular risk factors}

Tables 2 and 3 shows the associations of height, leg length, trunk length, and FEV , with cardiovascular risk factors. To facilitate comparison across tables all coefficients represent the increase (or decrease) in the specified risk factor associated with a one standard deviation increase in each measurement. Greater overall height was associated with reduced total cholesterol and fibrinogen concentrations, nonmanual social class (own and parental), higher $\mathrm{FEV}_{1}$, and birth weight. In women, but not men, stature was associated with a lower white blood cell count and BMI.
Leg length, but not trunk length, was inversely associated with systolic and diastolic blood pressure. Leg length was more strongly inversely associated with cholesterol levels than trunk length. Greater trunk length was associated with a raised body mass index in men, the opposite was seen with respect to leg length in both sexes. High leg to trunk length ratios were associated with favourable profiles of blood pressure, BMI, HDL, and total cholesterol in all subjects as well as lower glucose in men and lower fibrinogen in women. Current smokers were more likely to have higher leg to trunk length ratios. Associations with other cardiovascular risk factors differed little for the two components of stature. Social 


\begin{tabular}{|c|c|c|c|c|c|}
\hline & $\begin{array}{l}\text { (a) Height } \\
\text { (change }(95 \% \mathrm{Cl}), \mathrm{p} \\
\text { value per SD increase } \\
\text { in height) }\end{array}$ & $\begin{array}{l}\text { (b) Leg length } \\
\text { (change }(95 \% \mathrm{Cl}), \mathrm{p} \\
\text { value per SD increase } \\
\text { in leg length) }\end{array}$ & $\begin{array}{l}\text { (c) Trunk length } \\
\text { (change }(95 \% \mathrm{Cl}), \mathrm{p} \\
\text { value per SD increase } \\
\text { in trunk length) }\end{array}$ & $\begin{array}{l}\text { (d) Leg: trunk ratio } \\
\text { (change }(95 \% \mathrm{Cl}), \mathrm{p} \\
\text { value per SD increase } \\
\text { in ratio) }\end{array}$ & $\begin{array}{l}\text { (e) } \mathrm{FEV}_{1} \\
\text { (change }(95 \% \mathrm{Cl}), \mathrm{p} \\
\text { value per SD increase } \\
\text { in } \mathrm{FEV}_{1} \text { ) }\end{array}$ \\
\hline \multicolumn{6}{|c|}{ Cigarette smoking status } \\
\hline \multicolumn{6}{|c|}{ Men } \\
\hline Never/ex smoker & 1.00 & 1.00 & 1.00 & 1.00 & 1.00 \\
\hline Current smoker & $\begin{array}{l}0.86 \quad(0.74 \text { to } 0.99) \\
p=0.04\end{array}$ & $\begin{array}{l}1.00(0.87 \text { to } 1.16) \\
p=0.96\end{array}$ & $\begin{array}{l}0.76 \quad(0.66 \text { to } 0.87) \\
p<0.001\end{array}$ & $\begin{array}{l}1.23(1.06 \text { to } 1.42) \\
p=0.01\end{array}$ & $\begin{array}{l}0.62(0.52 \text { to } 0.74) \\
p<0.001\end{array}$ \\
\hline \multicolumn{6}{|l|}{ Women } \\
\hline Never/ex smoker & 1.00 & 1.00 & 1.00 & 1.00 & 1.00 \\
\hline Current smoker & $\begin{array}{l}1.03(0.91 \text { to } 1.18) \\
p=0.63\end{array}$ & $\begin{array}{l}1.10(0.96 \text { to } 1.25) \\
p=0.18\end{array}$ & $\begin{array}{l}0.95(0.84 \text { to } 1.08) \\
p=0.44\end{array}$ & $\begin{array}{l}1.14(1.00 \text { to } 1.30) \\
p=0.05\end{array}$ & $\begin{array}{l}0.58(0.50 \text { to } 0.68) \\
p<0.001\end{array}$ \\
\hline \multicolumn{6}{|l|}{ Own social class } \\
\hline \multicolumn{6}{|l|}{ Men } \\
\hline Non-manual & 1.00 & 1.00 & 1.00 & 1.00 & 1.00 \\
\hline Manual & $\begin{array}{l}0.72(0.63 \text { to } 0.82) \\
p<0.001\end{array}$ & $\begin{array}{l}0.80(0.71 \text { to } 0.91) \\
p=0.001\end{array}$ & $\begin{array}{l}0.71(0.61 \text { to } 0.81) \\
p<0.001\end{array}$ & $\begin{array}{l}1.04(0.91 \text { to } 1.19) \\
p=0.56\end{array}$ & $\begin{array}{l}0.71(0.62 \text { to } 0.83) \\
p<0.001\end{array}$ \\
\hline \multicolumn{6}{|l|}{ Women } \\
\hline Non-manual & 1.00 & 1.00 & 1.00 & 1.00 & 1.00 \\
\hline Manual & $\begin{array}{l}0.82(0.72 \text { to } 0.95) \\
p=0.01\end{array}$ & $\begin{array}{l}0.84 \quad(0.73 \text { to } 0.96) \\
p=0.01\end{array}$ & $\begin{array}{l}0.87 \quad(0.76 \text { to } 0.99) \\
p=0.04\end{array}$ & $\begin{array}{l}0.93 \quad(0.81 \text { to } 1.06) \\
p=0.28\end{array}$ & $\begin{array}{l}0.78 \quad(0.67 \text { to } 0.91) \\
p=0.001\end{array}$ \\
\hline \multicolumn{6}{|l|}{ Father's social class } \\
\hline \multicolumn{6}{|l|}{ Men } \\
\hline Non-manual & 1.00 & 1.00 & 1.00 & 1.00 & 1.00 \\
\hline Manual & $\begin{array}{l}0.84 \quad(0.72 \text { to } 0.97) \\
p=0.02\end{array}$ & $\begin{array}{l}0.89(0.77 \text { to } 1.02) \\
p=0.10\end{array}$ & $\begin{array}{l}0.84 \text { (0.72 to } 0.97) \\
p=0.02\end{array}$ & $\begin{array}{l}1.01 \quad(0.88 \text { to } 1.16) \\
p=0.89\end{array}$ & $\begin{array}{l}0.74 \quad(0.63 \text { to } 0.87) \\
p<0.001\end{array}$ \\
\hline \multicolumn{6}{|l|}{ Women } \\
\hline Non-manual & 1.00 & 1.00 & 1.00 & 1.00 & 1.00 \\
\hline Manual & $\begin{array}{l}0.83(0.73 \text { to } 0.94) \\
p=0.003\end{array}$ & $\begin{array}{l}0.83 \text { (0.73 to } 0.95) \\
p=0.01\end{array}$ & $\begin{array}{l}0.88(0.77 \text { to } 1.00) \\
p=0.05\end{array}$ & $\begin{array}{l}0.91 \text { (0.79 to } 1.04) \\
p=0.15\end{array}$ & $\begin{array}{l}0.77 \quad(0.66 \text { to } 0.88) \\
p<0.001\end{array}$ \\
\hline
\end{tabular}

class differences for leg length were similar to those for trunk length. In a separate analysis, based on the 677 subjects with recorded birthweight data, we repeated the analysis of leg length-risk factor associations, controlling for birth weight (data not shown). There was no evidence that birth weight confounded associations between leg length and cholesterol, fibrinogen or body mass index however the inverse associations of leg length with blood pressure was attenuated.

$\mathrm{FEV}_{1}$ was more strongly associated with systolic blood pressure, fibrinogen, and white cell count than was height, leg length, trunk length or leg:trunk ratio. Unlike height, FEV, was associated with reduced random glucose and was more strongly

Table 4 Age adjusted change in levels of cardiovascular risk factors per standard deviation (SD) increase in own height adjusted for mid-parental height*

\begin{tabular}{|c|c|c|c|c|}
\hline & Men & & Women & \\
\hline & Increase $(95 \% \mathrm{Cl})$ & p Value & Increase $(95 \% \mathrm{Cl})$ & p Value \\
\hline Systolic blood pressure (mm Hg) & $-0.97(-2.17$ to 0.23$)$ & 0.11 & $-0.78(-1.86$ to 0.31$)$ & 0.16 \\
\hline Diastolic blood pressure $(\mathrm{mm} \mathrm{Hg})$ & $-0.34(-1.18$ to 0.50$)$ & 0.42 & $-0.10(-0.78$ to 0.59$)$ & 0.78 \\
\hline Total cholesterol $(\mathrm{mmol} / \mathrm{l})$ & $-0.12(-0.20$ to -0.04$)$ & 0.002 & $-0.10(-0.16$ to -0.04$)$ & 0.001 \\
\hline High density lipoprotein cholesterol (mmol/l) & $-0.01 \quad(-0.03$ to 0.02$)$ & 0.66 & $-0.08(-0.04$ to 0.02$)$ & 0.59 \\
\hline Random glucose (mmol/l) & $-0.03(-0.17$ to 0.11$)$ & 0.68 & $0.01(-0.08$ to 0.09$)$ & 0.88 \\
\hline Fibrinogen (g/l) & $-0.07(0.13$ to -0.01$)$ & 0.02 & $-0.05(-0.11$ to 0.00$)$ & 0.05 \\
\hline White blood cell count $\left(10^{9} / \mathrm{I}\right)$ & $0.05(-0.10$ to 0.19$)$ & 0.55 & $-0.20(-0.33$ to -0.06$)$ & 0.004 \\
\hline Forced expiratory volume in 1 second (I) & $0.26(0.22$ to 0.31$)$ & $<0.001$ & $0.21 \quad(0.18$ to 0.24$)$ & $<0.001$ \\
\hline Forced vital capacity (I) & $0.41 \quad(0.35$ to 0.46$)$ & $<0.001$ & $0.30(0.26$ to 0.33$)$ & $<0.001$ \\
\hline Recorded birth weight (kg) & $0.13(0.06$ to 0.20$)$ & $<0.001$ & $0.14(0.08$ to 0.21$)$ & $<0.001$ \\
\hline \multirow[t]{2}{*}{ Body mass index $\left(\mathrm{kg} / \mathrm{m}^{2}\right)$} & $0.08(-0.26$ to 0.42$)$ & 0.63 & $-0.61(-0.96$ to -0.27$)$ & 0.001 \\
\hline & OR $(95 \% \mathrm{Cl})$ & p Value & OR $(95 \% \mathrm{Cl})$ & p Value \\
\hline \multicolumn{5}{|l|}{ Cigarette smoking status } \\
\hline Never/ex smoker & 1.00 & & 1.00 & \\
\hline Current smoker & $0.91(0.76$ to 1.09$)$ & 0.32 & $0.99(0.84$ to 1.16$)$ & 0.86 \\
\hline \multicolumn{5}{|l|}{ Own social class } \\
\hline Non-manual & 1.00 & & 1.00 & \\
\hline Manual & $0.73(0.62$ to 0.87$)$ & $<0.001$ & $0.86(0.72$ to 1.02$)$ & 0.08 \\
\hline \multicolumn{5}{|l|}{ Father's social class } \\
\hline Non-manual & 1.00 & & 1.00 & \\
\hline Manual & $1.19(0.99$ to 1.42$)$ & 0.06 & 1.03 (0.89 to 1.20$)$ & 0.69 \\
\hline
\end{tabular}


associated with smoking. Associations with $\mathrm{FEV}_{1}$ were essentially unchanged in models controlling for the possible confounding effects of physical activity (results not shown).

\section{Effects of parental height on offspring's height-cardiovascular risk factor association}

Controlling for mid-parental height had little effect on the associations between height and cardiovascular risk profile in their offspring (table 4). The association between stature and father's social class was, however, abolished in these models. This indicates that parental stature may act as a marker of parental socioeconomic position as well a marker of genetically determined height potential.

In separate models we assessed the effects of controlling for maternal and paternal height separately. Our findings were similar to those seen in models controlling for mid-parental height (see above, data not shown).

\section{DISCUSSION}

\section{Main findings}

This analysis suggests that taller men and women have more favourable cardiovascular risk profiles than shorter people. $\mathrm{FEV}_{1}$ is more strongly associated than is height with the cardiovascular risk factors examined, suggesting it may be a better biomarker for the factors underlying associations between pre-adult exposures and adult cardiovascular disease. ${ }^{17}$ Associations with stature were largely unchanged in models controlling for parental height, indicating genetic factors may not underlie the observed height-risk factor associations. Furthermore, analysis of the subset of study members with birthweight data suggests that some staturecardiovascular risk factor associations are independent of prenatal influences.

Three important risk factors for CHD-raised blood pressure, BMI and, to a lesser extent, cholesterol-were more strongly associated with leg length than trunk length. Our findings for cholesterol and, to a lesser degree, blood pressure are consistent with those in our analysis of the Caerphilly cohort; in that analysis adverse patterns of insulin resistance and fibrinogen were also more strongly related to short leg length. ${ }^{15}$ In Midspan study members blood glucose levels were lower in men with higher leg: trunk ratios.

Unlike previous analyses, ${ }^{15} 23-25$ we found no evidence that social class differences in height were in greater part attributable to leg length than trunk length. The associations of $\mathrm{FEV}_{1}$ with leg length were slightly weaker than their relation with trunk length but were stronger than those we found reported in Caerphilly where we used a height adjusted measure of lung function..$^{15}$ In the analyses reported here we used raw $\mathrm{FEV}_{1}$ as we were interested in an absolute measure of lung development rather than lung function in relation to size.

\section{Strengths and limitations}

One of the main strengths of this study is the availability of detailed anthropometry (including sitting height) and lung function tests. Furthermore, the availability of parental height measurements enable an assessment of the importance of genetic influences in the height-CHD risk factor associations.

There are two main limitations to this analysis. Firstly, only $2338(48 \%)$ of the offspring identified took part in the study. The main reason for non-participation was that these individuals had moved away from the Paisley and Renfrew area and so were not invited to take part (the response rate was $73 \%$ in those invited). We have no reason to believe that exposure-risk factor associations are likely to be different in the individuals examined compared with those who were not. In support of this suggestion, $\mathrm{FEV}_{1}$-mortality associations are similar in the parents whose offspring participated in the study and those among parents whose offspring did not

\section{Key points}

- Taller people and those with good lung function $\left(\mathrm{FEV}_{1}\right)$ are at reduced risk of coronary heart disease (CHD).

- Leg length, an indicator of pre-pubertal nutritional status, seems to be the component of height most strongly associated with risk.

- In a study of 2338 men and women aged 30-59 we found that taller people and those with better lung function had more favourable cardiovascular risk factor profiles. Associations were strongest with lung function.

- Height (particularly leg length) and FEV 1 may both be markers for childhood exposures which influence growth and CHD risk.

- Genetic influences do not seem to underlie height-CHD risk factor associations.

(Upton M, manuscript in preparation). Secondly, we had limited information on birth weight (29\% of subjects only) and so were unable to fully assess its impact on observed associations in the full dataset. As previously reported, ${ }^{26}$ associations of birth weight with leg length and trunk length were similar, suggesting birth weight is unlikely to confound the observed differential associations with leg length. However, there was some evidence that birth weight confounded the associations of leg length with blood pressure.

\section{Early life and childhood influences on the development} of CHD

The aetiology of CHD is complex and involves several pathological processes. The importance of development in utero and in infancy is indicated by associations of both low birth weight and weight at 1 year with a high risk of CHD. ${ }^{27-29}$ The role of exposures in the first two decades of life in CHD development is supported by postmortem studies that reveal that around $50 \%$ of young men have some evidence of atherosclerosis (fatty streaks or plaques) in their coronary vessels. ${ }^{30}$ Blood pressure, blood lipids, body mass index, and smoking in childhood predict the extent of such postmortem atherosclerotic changes. ${ }^{31}$ Just as birth weight is used as a biomarker for in utero exposures, our findings suggest that height and FEV may be used as biomarkers for a range of exposures influencing post-natal growth such as diet, exposure to infection, and stress. ${ }^{12}{ }^{17}$ These factors in turn may have long term influences on the risk of developing atherosclerosis as indicated by height-CHD associations. ${ }^{1-615}$ The distinct importance of childhood exposures, over and above those acting in utero, is supported by findings in two prospective studies where adjustment for birth weight did not greatly influence observed height-CHD associations. ${ }^{23}$ While adult height is a marker for exposures influencing growth throughout childhood, leg length seems to be a marker for factors acting in the pre-pubertal period. Recent studies indicate that longer leg length is associated with breast feeding, energy rich diets at age 2 and affluent social circumstances..$^{24} 32$ Thus analyses reporting that leg length is the component of height most strongly related to later risk of $\mathrm{CHD}^{7}{ }^{15}$ indicate that one (or more) of these exposures pre-pubertally may be important in generating CHD risk.

\section{FEV $_{1}$ and cardiovascular disease}

Findings from the few studies ${ }^{33-36}$ that have examined associations between lung function and cardiovascular risk factor levels are broadly consistent with those reported in this paper. In the Paisley and Renfrew cohort, which includes the parents of subjects forming the basis of our analyses, higher FEV was associated with lower body mass index and cholesterol levels in men and women but there was no association with diastolic blood pressure. ${ }^{33}$ Associations between $\mathrm{FEV}_{1}$ and CHD mortality in the Paisley and Renfrew cohort were independent of 
other coronary risk factors including smoking, cholesterol, diastolic blood pressure, body mass index, and social class. ${ }^{33}$ In Framingham, vital capacity was inversely associated with diastolic blood pressure, but associations with blood sugar and cholesterol differed in different age and sex groups. ${ }^{35}$ In the Gothenburg cohort of middle age women, cholesterol and triglycerides levels decreased with increases in peak expiratory flow rates. ${ }^{34}$

While previous research indicates that FEV, seems to be a more powerful predictor of CHD risk than height, height has two main advantages over FEV, as an epidemiological biomarker for early life exposures. Firstly, it is straightforward to measure accurately and is also self reported with reasonable precision. Secondly, with the exception of age related changes, it is little influenced by exposures subsequent to growth cessation. In contrast FEV 1 may be affected by smoking-itself a powerful predictor of CHD risk.

\section{What this study contributes to an understanding of childhood influences on CHD}

This analysis provides some support for the importance of childhood exposures in generating height-CHD associations. We have reported four main findings. Firstly, we have found associations between a range of well recognised cardiovascular risk factors and both height and $\mathrm{FEV}_{1}$. Secondly, stature-risk factor associations are generally stronger for leg length than trunk length. This hints at the importance of pre-pubertal exposures, in generating height-CHD associations. Thirdly, controlling for parental stature had little effect on height-risk factor associations. This suggests that genetic factors may not underlie associations between height and cardiovascular risk factor profiles. Lastly, we found that $\mathrm{FEV}_{1}$ was more strongly associated with cardiovascular risk factor profiles than the anthropometric measures. If $\mathrm{FEV}_{1}$ is acting as a biomarker for childhood exposures in the $\mathrm{FEV}_{1}$-cardiovascular risk profile associations, then this finding suggests it is a more sensitive measure of the childhood exposures, such as diet and socioeconomic circumstances, that lead to the development of CHD than is childhood stature.

\section{ACKNOWLEDGEMENTS}

We wish to acknowledge the help of Catherine Ferrell, Jane Goodfellow, Michere Beaumont, and Helen Richards for contacting the offspring and the research nurses-Claire Bidwell, Julie Hunter, Evelyn Lapsley, Iona MacTaggart, Nicola McPherson, and Sarah Morganwho made the measurements. We also thank Gordon Lowe and Anne Rumley for white cell count and fibrinogen assays, Chris Packard for lipid assays, and Alan McLelland for glucose assays.

\section{Authors' affiliations}

D Gunnell, E Whitley, G Davey Smith, Department of Social Medicine, University of Bristol, Bristol, UK

M N Upton, A McConnachie, G C M Watt, Department of General Practice, University of Glasgow, Glasgow, UK

Funding: this work is supported by grants from the Wellcome Trust and the NHS Research and Development Programme.

Conflicts of interest: none.

\section{REFERENCES}

1 Marmot MG, Shipley M, Rose G. Inequalities in death-specific explanations of a general pattern? Lancet 1984;i: 1003-6.

2 Yarnell JGW, Limb ES, Layzell JM, et al. Height: a risk marker for ischaemic heart disease. Eur Heart J 1992;13:1602-5.

3 Rich-Edwards JW, Manson JE, Stampfer M, et al. Height and the risk of cardiovascular disease in women. Am J Epidemiol 1995:142:909-917.

4 Hebert PR, Rich-Edwards JW, Manson JE, et al. Height and incidence of cardiovascular disease in male physicians. Circulation 1993;88: 1437-43

5 Wannamethee SG, Shaper AG, Whincup PH, et al. Adult height, stroke, and coronary heart disease. Am J Epidemiol 1998;148:106976.
6 Leon DA, Davey Smith G, Shipley M, et al. Adult height and mortality in London: early life, socioeconomic confounding, or shrinkage? J Epidemiol Community Health 1995;49:5-9.

7 Gunnell DJ, Davey Smith G, Frankel S, et al. Childhood leg length and adult mortality: follow up of the Carnegie (Boyd Orr) Survey of Diet and Health in Pre-war Britain. J Epidemiol Community Health 1998;52:142-52

8 Palmer JR, Rosenberg L, Shapiro S. Stature and the risk of myocardial infarction in women. Am J Epidemiol 1990;132:27-32.

9 Sacca L, Cittadini A, Fazio S. Growth hormone and the heart. Endocr Rev 1994:15:555-73.

10 Rosén T, Bengtsson BẢ. Premature mortality due to cardiovascular disease in hypopituitarism. Lancet 1990;336:285-8.

11 Gerver WJM, Bruin RD. Relationship between height, sitting height and subischial leg length in Dutch children: presentation of normal values. Acta Paediatr 1995:84:532-5.

12 Gunnell D. Can adult anthropometry be used as a biomarker for prenatal and childhood exposures? Int J Epidemiol 2002;31:390-4.

13 Tanner JM, Hayashi T, Preece MA, et al. Increase in length of leg relative to trunk in Japanese children and adults from 1957 to 1977 : comparison with British and with Japanese Americans. Ann Hum Biol 1982;9:411-23.

14 Udjus LG. Anthropometrical changes in Norwegian men in the twentieth century. Oslo: Universitetsforlaget, 1964.

15 Davey Smith G, Greenwood R, Gunnell D, et al. Leg length, insulin resistance, and coronary heart disease risk: The Caerphilly Study. J Epidemiol Community Health 2001;55:867-72.

16 Davey Smith G, Hart C, Upton $M$, et al. Height and risk of death among men and women: aetiological implications of associations with cardiorespiratory disease and cancer mortality. J Epidemiol Community Health 2000;54:97-103.

17 Strachan DP. Ventilatory function, height, and mortality among lifelong non-smokers. J Epidemiol Community Health 1992:46:66-70.

18 Hawthorne VM, Watt GCM, Hart CL, et al. Cardiorespiratory disease in men and women in urban Scotland: baseline characteristics of the Renfrew/Paisley (Midspan) population study. Scott Med J 1995;40:102-7.

19 Upton MN, McConnachie A, McSharry C, et al. Intergenerational 20 year trends in the prevalence of asthma and hay fever in adults: the Midspan family study surveys of parents and offspring. BM 2000;321:88-92.

20 Lowe GDO, Upton MN, Rumley A, et al. Different effects of oral and transdermal hormone replacement therapies on factor IX, APC resistance, t-PA, PAl and C-reactive protein: a cross sectional population survey. Thromb Haemost 2001;86:550-6

21 Upton MN, Ferrell C, Bidwell C, et al. Improving the quality of spirometry in an epidemiological study: The Renfrew-Paisley (Midspan) family study. Public Health 2000;1 14:353-60.

22 StataCorp. Stats statistical software: release 5.0. College Station, TX: Stata Corporation, 1996.

23 Billewicz WZ, Thomson AM, Fellowes HM. A longitudinal study of growth in Newcastle upon Tyne adolescents. Ann Hum Biol 1983;10:125-33.

24 Gunnell D, Davey Smith G, Frankel S, et al. Socio-economic and dietary influences on leg length and trunk length in childhood: a reanalysis of the Carnegie (Boyd Orr) survey of diet and health in prewar Britain (1937-39). Paediatr Perinat Epidemiol 1998;12:96-1 13

25 Wadsworth MEJ, Hardy RJ, Paul AA, et al. Leg and trunk length at 43 years in relation to childhood health, diet and family circumstances; evidence from the 1946 national birth cohort. Int J Epidemiol 2002;31:383-90

26 Gunnell D, Davey Smith G, McConnachie A, et al. Separating in-utero and postnatal influences on later disease. Lancet 1999;354:1526-7.

27 Barker DJP. Fetal and infant origins of adult disease. London: BM Publishing Group, 1992.

28 Frankel S, Elwood P, Sweetnam P, et al. Birthweight, body mass index in middle age, and incident coronary heart disease. Lancet 1996;348: 1478-80.

29 Leon DA, Lithell HO, Vågerö D, et al. Reduced fetal growth rate and increased risk of death from ischaemic heart disease: cohort study of 15000 Swedish men and women born 1915-1929. BM 1998;317:241-5

30 McNamara JJ, Molot MA, Stremple JF, et al. Coronary artery disease in combat casualties in Vietnam. JAMA 1971;216:1185-7.

31 Berenson GS, Srinvasan SR, Bao W, et al. Association between multiple cardiovascular risk factors and atherosclerosis in children and young adults. N Engl J Med 1998;338:1650-6

32 Martin R, Gunnell D, Mangtani P, et al. Association between breast feeding and growth in childhood through to adulthood: the Boyd Or cohort study. J Epidemiol Community Health 2000:54:784 Arch Dis Child Fetal Neonatal Ed 2002:87:F193-201.

33 Hole DJ, Watt GCM, Davey Smith G, et al Impaired lung function and mortality risk in men and women: findings from the Renfrew and Paisley prospective population study. BM 1996;313:711-15.

34 Persson C, Bengtsson C, Lapidus L, et al. Peak expiratory flow and risk of cardiovascular disease and death. A 12-year follow-up of participants in the population study of women in Gothenburg, Sweden. Am J Epidemiol 1986;124:942-8.

35 Kannel WB, Seidman JM, Fercho W, et al. Vital capacity and congestive heart failure. The Framingham study. Circulation 1974:49:1160-6.

36 Lange $\mathbf{P}$, Nyboe J, Appleyard $M$, et al. Spirometric findings and mortality in never-smokers. J Clin Epidemiol 1990;43:867-73. 